\title{
Failure of cytotoxic drugs to suppress immune responses of patients with rheumatoid arthritis
}

\author{
E. J. DENMAN, ${ }^{1}$ A. M. DENMAN, ${ }^{1}$ B. M. GREENWOOD, D. GALL, ${ }^{2}$ \\ AND R. B. HEATH ${ }^{3}$ \\ From the M.R.C. Rheumatism Unit, Canadian Red Cross Memorial Hospital, Taplow, Maidenhead, Berks.
}

Cytotoxic drugs suppress many forms of immune and inflammatory response in animals (Gabrielsen and Good, 1967). It has been argued that their immunosuppressive properties justify the use of these drugs in the treatment of putative autoimmune diseases in man. As a result they have been used to treat chronic inflammatory diseases including rheumatoid arthritis (Mason, Currey, Barnes, Dunne, Hazleman, and Strickland, 1969). It is pertinent to ask, however, whether cytotoxic drugs do indeed suppress the immune response of patients with rheumatoid arthritis and to determine whether any such immunosuppression can be correlated with clinical improvement.

\section{Material and methods}

\section{PATIENTS AND CONTROLS}

All patients at Taplow who received cytotoxic drugs for the treatment of rheumatoid arthritis or juvenile rheumatoid arthritis (Still's disease) during the period March, 1966, to January, 1969, were studied. The clinical features of these twenty patients (Group A) are given in Table I (opposite).

One of these patients (Case 6) had some of the clinical features of disseminated lupus erythematosus. Because treatment with cytotoxic drugs was reserved for patients with complications, including amyloidosis, who had failed to respond to other drugs, this group consists of a small number of selected persons with severe disease. The diagnosis of amyloid disease was confirmed by rectal biopsy.

A second group of 39 patients with severe rheumatoid arthritis or Still's disease was also studied (Group B). Their clinical features are summarized in Table II. Since their disease did not justify the use of cytotoxic drugs by our criteria, patients in this group had fewer disease complications than those in Group A. All in both groups had previously been treated with a combination of salicylates, phenylbutazone, chloroquine, Myocrisin, and steroids. The majority were receiving prednisone at the
Table II Clinical features of 39 patients with classical rheumatoid arthritis or Still's disease not receiving cytotoxic drugs (group B)

\begin{tabular}{|c|c|c|c|c|c|c|}
\hline \multirow{2}{*}{$\begin{array}{l}\text { Diagnosis } \\
\\
\end{array}$} & \multirow{2}{*}{$\begin{array}{l}\text { No. } \\
\text { of } \\
\text { cases }\end{array}$} & \multirow{2}{*}{$\begin{array}{l}\text { ESR }(\mathrm{mm} . \\
\text { in } 1 \mathrm{hr}) \\
\begin{array}{l}\text { mean } \\
\text { (range) }\end{array}\end{array}$} & \multirow{2}{*}{$\begin{array}{l}\text { Functional } \\
\text { status } \\
\begin{array}{l}\text { mean } \\
\text { (range) }\end{array}\end{array}$} & \multicolumn{3}{|c|}{ Latex } \\
\hline & & & & $+t$ & & - \\
\hline $\begin{array}{l}\text { Rheumatoid } \\
\text { arthritis }\end{array}$ & 33 & $\begin{array}{r}59 \cdot 5(8 \cdot 0- \\
100 \cdot 0)\end{array}$ & $2 \cdot 3 \quad(1-4)$ & 21 & 9 & 3 \\
\hline $\begin{array}{l}\text { Still's } \\
\text { disease }\end{array}$ & 6 & $\begin{array}{r}62 \cdot 5(34 \cdot 0- \\
84 \cdot 0)\end{array}$ & $2 \cdot 2 \quad(1-3)$ & 0 & 0 & 0 \\
\hline
\end{tabular}

time of study but none was receiving a dose greater than $11 \mathrm{mg}$. daily.

Twenty healthy subjects, mainly hospital staff, served as controls (Group C).

The age and sex distribution of the three groups was comparable.

\section{THERAPEUTIC VALUE OF CYTOTOXIC DRUGS}

This report is concerned primarily with the immunological responses of patients treated with cytotoxic drugs and is not an account of the therapeutic trial of these drugs currently in progress (Zutshi, Ansell, and Bywaters, unpublished). Thus only the principal change in disease activity associated with cytotoxic drug therapy are given in Table I.

Functional activity was assessed using five grades of activity (Empire Rheumatism Council, 1960). Haematological and biochemical determinations were performed by standard methods; absolute lymphocyte counts were determined using a combination of Coulter counting and May-Grünwald Giemsa stained films. Latex tests were carried out on the sera of patients in Group A by the method of Valkenburg (1963) and on the sera of patients in Group B by an adaptation (Bywaters and Scott, 1960) of the method of Singer and Plotz (1956).

\footnotetext{
1 Present address: Department of Bacteriology, Karolinska Institute, Stockholm 60, Sweden.

2 Wellcome Research Laboratories, Beckenham, Kent.

3 Department of Virology, St. Bartholomew's Hospital, London, E.C.1.

Reprint requests to E. J. Denman.
} 
Table I Clinical features of 20 patients with rheumatoid arthritis and Still's disease treated with cytotoxic drugs (group $A$ )

\begin{tabular}{|c|c|c|c|c|c|c|c|c|c|c|c|c|c|c|}
\hline \multirow{3}{*}{$\begin{array}{l}\begin{array}{l}\text { Patient } \\
\text { no. }\end{array} \\
1\end{array}$} & \multirow{3}{*}{$\begin{array}{l}\text { Sex } \\
\mathbf{M}\end{array}$} & \multirow{3}{*}{$\begin{array}{l}\text { Age (yrs) } \\
60\end{array}$} & \multirow{3}{*}{$\begin{array}{l}\begin{array}{l}\text { Diagnosis* } \\
\text { and } \\
\text { complications }\end{array} \\
\text { Classical RA } \\
\text { Neuropathy } \\
\end{array}$} & \multicolumn{3}{|c|}{ Before treatment } & \multicolumn{3}{|c|}{ After treatment } & \multirow{3}{*}{$\begin{array}{l}\text { Change } \\
\text {-in clinical } \\
\text { status }\end{array}$} & \multicolumn{4}{|c|}{ Details of cytotoxic drugs } \\
\hline & & & & \multirow{2}{*}{$\begin{array}{l}\begin{array}{l}\text { Func- } \\
\text { tional } \\
\text { status } \\
\text { (joints) }\end{array} \\
3\end{array}$} & \multicolumn{2}{|c|}{$\begin{array}{l}\text { Erythro- Latex } \\
\text { cyte sedi- } \\
\text { mentation } \\
\text { rate }\end{array}$} & \multirow{2}{*}{$\begin{array}{l}\begin{array}{l}\text { Func- } \\
\text { tional } \\
\text { status } \\
\text { (joints) }\end{array} \\
3\end{array}$} & \multicolumn{2}{|c|}{$\begin{array}{l}\text { Erythro- Latex } \\
\text { cyte sedi- } \\
\text { mentation } \\
\text { rate }\end{array}$} & & \multirow{2}{*}{$\begin{array}{l}\text { Drug } \\
\text { C }\end{array}$} & $\begin{array}{l}\text { Dose } \\
\text { range } \\
\text { (mg.) }\end{array}$ & \multirow{2}{*}{$\begin{array}{l}\begin{array}{l}\text { Duration } \\
\text { of treat- } \\
\text { ment } \\
\text { (wks) }\end{array} \\
11\end{array}$} & \multirow{2}{*}{$\begin{array}{l}\text { Side-effects } \\
\begin{array}{l}\text { Gluteal } \\
\text { abcess }\end{array}\end{array}$} \\
\hline & & & & & 60 & 5120 & & 83 & 5120 & & & $6-14$ & & \\
\hline 2 & $\mathbf{F}$ & 19 & Still's disease & 3 & 81 & 0 & 2 & 40 & $\overline{0}$ & $\overline{\text { Better }}$ & $\mathrm{C}$ & $4-6$ & 34 & $\begin{array}{l}\text { Thrombocy- } \\
\text { topenia }\end{array}$ \\
\hline 3 & $\mathbf{F}$ & 21 & $\begin{array}{l}\text { Still's disease } \\
\text { Amyloid }\end{array}$ & 3 & 122 & $\overline{0}$ & $\overline{4}$ & 81 & $\overline{0}$ & $\overline{\text { Worse }}$ & $\overline{\mathbf{C}}$ & 4 & 14 & $\overline{-}$ \\
\hline 4 & $\mathbf{M}$ & 58 & $\begin{array}{l}\text { Classical RA } \\
\text { Amyloid }\end{array}$ & 3 & 118 & 640 & 3 & 103 & 1280 & 0 & $\mathbf{C}$ & 4-14 & 40 & - \\
\hline 5 & $\mathbf{F}$ & 55 & $\begin{array}{l}\text { Classical RA } \\
\text { Neuropathy } \\
\text { Vasculitis }\end{array}$ & 3 & 660 & 1280 & 3 & 31 & 2560 & $\mathbf{0}$ & $\mathbf{A}$ & 150 & 11 & $\begin{array}{l}\text { Infected } \\
\text { dependent } \\
\text { ulcers }\end{array}$ \\
\hline 6 & $\mathbf{F}$ & 55 & $\begin{array}{c}\text { Probable SLE } \\
\text { Vasculitis }\end{array}$ & 1 & 54 & 0 & 1 & 57 & 0 & Better & $\mathbf{A}$ & $\begin{array}{l}150 \\
2-6\end{array}$ & $\begin{array}{l}10 \\
32\end{array}$ & - \\
\hline 7 & $\mathbf{M}$ & 52 & $\begin{array}{l}\text { Classical RA } \\
\text { Vasculitis }\end{array}$ & 3 & 93 & 2560 & 3 & 108 & 2560 & $\overline{\text { Worse }}$ & $\mathbf{C}$ & 6 & 10 & $\begin{array}{l}\text { Pneumonia } \\
\text { (died) }\end{array}$ \\
\hline 8 & $\mathbf{F}$ & 53 & Classical RA & 4 & 116 & 2560 & $\overline{4}$ & 110 & 2560 & $\overline{\text { Worse }}$ & $\bar{C}$ & 6 & 8 & $\begin{array}{l}\text { Pneumonia } \\
\text { (died) }\end{array}$ \\
\hline 9 & $\mathbf{M}$ & 39 & $\begin{array}{l}\text { Classical RA } \\
\text { Amyloid }\end{array}$ & 3 & 117 & 1280 & 3 & 150 & 1280 & Worse & $\mathbf{A}$ & 100 & 27 & $\begin{array}{l}\text { Bone } \\
\text { marrow } \\
\text { depression* }\end{array}$ \\
\hline 10 & $\mathbf{F}$ & 24 & $\begin{array}{l}\text { Still's disease } \\
\text { Amyloid }\end{array}$ & 3 & 113 & 0 & 3 & 110 & 0 & Worse & C & 6 & 6 & $\begin{array}{l}\text { Uraemia } \\
\text { (died) Throm- } \\
\text { bocytopenia } \\
\end{array}$ \\
\hline 11 & $\mathbf{F}$ & 52 & Classical RA & $\overline{4}$ & 60 & 1280 & 4 & 55 & 1280 & 0 & $\mathbf{A}$ & 125 & 12 & - \\
\hline 12 & $\mathbf{F}$ & 10 & $\begin{array}{l}\text { Still's disease } \\
\text { Doubtful amy- } \\
\text { loid-equivacol } \\
\text { biopsy }\end{array}$ & 2 & 113 & 0 & 2 & 80 & 0 & 0 & C & $2-4$ & 15 & - \\
\hline$\overline{13}$ & $\mathbf{M}$ & 15 & $\begin{array}{l}\text { Still's disease } \\
\text { Amyloid }\end{array}$ & 1 & 60 & 0 & 1 & 34 & 0 & 0 & C & $2-8$ & 53 & - \\
\hline 14 & $\mathbf{M}$ & 20 & $\begin{array}{l}\text { Still's disease } \\
\text { Amyloid }\end{array}$ & 2 & 60 & 0 & 2 & 38 & 0 & 0 & C & 8 & 12 & - \\
\hline$\overline{15}$ & $\mathbf{F}$ & 48 & $\begin{array}{l}\text { Classical RA } \\
\text { Vasculitis }\end{array}$ & 4 & 90 & 2560 & $\overline{4}$ & 105 & 2560 & 0 & $\overline{\mathbf{A}}$ & 100 & 11 & $\begin{array}{l}\text { Bone marrow } \\
\text { aplasia }\end{array}$ \\
\hline 16 & $\mathbf{F}$ & 60 & $\begin{array}{l}\text { Classical RA } \\
\text { Neuropathy }\end{array}$ & 3 & 80 & 5120 & 3 & 35 & 5120 & 0 & C & 8 & 6 & - \\
\hline 17 & $\mathbf{F}$ & 66 & $\begin{array}{l}\text { Classical RA } \\
\text { Arteritis }\end{array}$ & 3 & 30 & 1280 & 3 & 36 & 0 & Worse & $\underset{\mathbf{C}}{\mathbf{A}}$ & ${ }_{5-10}^{100}$ & $\begin{array}{r}12 \\
. \quad 5\end{array}$ & $\begin{array}{l}\text { Bone marrow } \\
\text { depression* } \\
\text { Septicaemia } \\
\text { (died) }\end{array}$ \\
\hline 18 & $\mathbf{M}$ & 10 & $\begin{array}{l}\text { Still's disease } \\
\text { Amyloid }\end{array}$ & 2 & 100 & 0 & 2 & 120 & 0 & 0 & C & $2-4$ & 26 & - \\
\hline$\overline{19}$ & $F$ & 55 & $\begin{array}{l}\text { Classical RA } \\
\text { Vasculitis }\end{array}$ & 3 & 67 & ++ & 3 & 52 & ++ & 0 & C & 2 & 6 & - \\
\hline 20 & $\mathbf{F}$ & 49 & $\begin{array}{l}\text { Classical RA } \\
\text { Neuropathy } \\
\text { Vasculitis }\end{array}$ & 4 & 31 & 1280 & 4 & 30 & 640 & 0 & C & $4-5$ & 38 & $\begin{array}{l}\text { Thrombo- } \\
\text { cytopenia }\end{array}$ \\
\hline
\end{tabular}

* Classical rheumatoid arthritis by criteria of American Rheumatism Association (1958) Still's disease by criteria of Ansell and Bywaters (1959) $\mathrm{C}=$ Chlorambucil $\mathrm{A}=$ Azathioprine ${ }^{*}$ Platelets $<100,000 / \mathrm{cu}$. mm. Neutrophils $<1,000 / \mathrm{cu}$. mm. Haemoglobin $<8 \mathrm{~g}$. per cent.

DOSAGE OF CYTOTOXIC DRUGS

Azathioprine (Imuran) and chlorambucil were used initially in a dose of $2.5 \mathrm{mg}$. $/ \mathrm{kg}$. bodyweight and 0.01 $\mathrm{mg} . / \mathrm{kg}$. bodyweight respectively. The dosage was subsequently adjusted to maintain a persistent lymphopenia; details of treatment are given in Table I. The results of treatment with both drugs are considered together as the number of patients on each drug was small.

\section{PLAN OF IMMUNOLOGICAL ASSESSMENT}

Patients receiving cytotoxic drugs (Group $A$ )

Immunological responses were measured before, during, and after treatment with cytotoxic drugs (Table III, overleaf). 
Alternate patients were immunized either with polyvalent influenza vaccine, "Flugen" (Antigen 1), or with tetanus toxoid (Antigen 2). The first antigen was given before treatment with cytotoxic drugs and the second was injected 3 weeks after treatment had been started, when the blood lymphocyte count had fallen. Only a single injection of "Flugen" was given, but the first injection of tetanus toxoid was followed by a second injection 6 to 8 weeks later and a third after 6 months. Patients who had previously been immunized with tetanus toxoid received a single "booster" injection. Patients receiving cytotoxic drug therapy for longer than 10 weeks were immunized with a third antigen, brucella vaccine (Antigen 3).

The agents used to transform lymphocytes in vitro were of two kinds: those which the patients might have encountered naturally or against which they had previously been immunized, and those used in active immunization in this study.

No attempt was made to distinguish between primary and secondary antibody responses, as a variable degree of natural immunity almost certainly existed to these antigens, which were chosen for ethical reasons. Accordingly a rise in antibody titre after immunization was the only factor analysed.

Table III Plan of immunological assessment in patients receiving cytotoxic drugs (group $A$ )

\begin{tabular}{|c|c|c|}
\hline Assessment & Antigen & Time tested \\
\hline $\begin{array}{l}\text { Lymphocyte re- } \\
\text { activity in vitro }\end{array}$ & $\begin{array}{l}\text { As listed in } \\
\text { Table IV }\end{array}$ & $\begin{array}{l}\text { Before and every } \\
3 \text { weeks during } \\
\text { treatment with } \\
\text { cytotoxic drugs }\end{array}$ \\
\hline $\begin{array}{l}\text { Circulating } \\
\text { antibody }\end{array}$ & $\begin{array}{l}\text { 'Flugen' (Ag. 1)* } \\
\text { Tetanus toxoid } \\
\text { (Ag. 2) } \\
\text { Brucella vaccine } \\
\text { (Ag. 3) }\end{array}$ & $\begin{array}{l}\text { Before and } 3 \\
\text { weeks after } \\
\text { immunization }\end{array}$ \\
\hline kin & $\begin{array}{l}\text { Tuberculoprotein } \\
\text { (PPD) } \\
\text { Streptokinase }\end{array}$ & $\begin{array}{l}\text { Before and every } \\
3 \text { weeks during } \\
\text { treatment with } \\
\text { cytotoxic drugs }\end{array}$ \\
\hline
\end{tabular}

* Ag. 1 or Ag. 2 given to alternate patients before starting treatment with cytotoxic drugs.

Patients with rheumatoid arthritis not receiving cytotoxic drugs (Group B)

The same protocol was followed for patients in this group as for patients in Group A except that Antigen 2 was administered 8 weeks after Antigen 1. Three patients originally in Group B subsequently received cytotoxic drugs and were placed in Group A (Cases 3, 7, and 18, Table I); they were immunized with Antigen 3 (brucella vaccine) after treatment had been started. Only sixteen patients in Group B were actively immunized; studies in the remainder were confined to lymphocyte transformation tests.

\section{Normal controls (Group C)}

Eleven of the twenty controls were immunized with Antigens 1 and 2. Lymphocyte transformation tests were carried out in all twenty.

\section{CLINICAL CORRELATION}

Full blood counts were obtained twice weekly from patients in Group A and monthly from those in Group B. Regular clinical and laboratory assessments were made during the course of treatment as part of the clinical trial previously mentioned, but only the findings at the beginning and end of treeatment are included in this paper (Table I).

\section{IMMUNOLOGICAL METHODS \\ Lymphocyte transformation tests}

Lymphocytes from $20 \mathrm{ml}$. heparinized venous blood were cultured in Parker 199 medium and antigens were added on the first day of culture. Tritiated thymidine $\left(\mathrm{H}^{3}\right.$ thymidine) was added on the 4 th and 5 th days of culture, and cells were harvested on the 6th day, except for cultures stimulated with phytohaemagglutinin (PHA) and purified protein derivative (PPD) which were harvested after 3 days and 5 days respectively. Nucleic acids were extracted and the amount of $\mathrm{H}^{3}$ thymidine incorporation was measured by liquid scintillation counting. Autoradiographs were prepared with Kodak AR 10 stripping film and were exposed for 7 days. Full details of these procedures have been given elsewhere (Vischer, 1966; Denman and Denman, 1968). Whenever possible $2.0 \times 10^{6}$ mononuclear cells in $5 \mathrm{ml}$. were used in duplicate cultures, but in patients with profound lymphopenia it was often necessary to use $1.0 \times 10^{6}$ per culture in half the usual volume of medium. A positive response to an antigen or to PHA has been defined as a culture in which the incorporation of $\mathrm{H}^{3}$ thymidine, measured by liquid scintillation counting and autoradiography, was two or more times greater than $\mathrm{H}^{3}$ thymidine incorporation in cultures of mononuclear cells from the same patient to which antigen or PHA had not been added.

Several preliminary experiments were undertaken to define the most suitable culture conditions for this study, as it was apparent that lymphocyte yields from patients receiving cytotoxic drugs would be small. Filtration of blood lymphocytes through glass bead columns, to obtain cell suspensions free from granulocytes and consisting of 80 per cent. or more of lymphocytes, did not significantly affect the response to PHA. Similarly, this response was not materially altered by washing the lymphocytes and re-suspending them in autologous serum or foetal calf serum. Accordingly all cultures were subsequently set up in autologous plasma made up to 20 per cent. of the final volume with foetal bovine serum when necessary. There was initial concern that circulating cytotoxic drugs might suppress the ability of cultured lymphocytes to transform as a result of a direct action in vitro. However, the fact that the procedures described above did not influence the transforming capacity of lymphocytes obtained from patients who were receiving cytotoxic drugs at the time of culture justified the decision to set up cultures in autologous plasma.

The amount of PHA or antigen required to give the maximum degree of stimulation was established in a series of experiments in which the concentration per culture was varied from $1 / 10$ th to 10 times the concentration given in Table IV (opposite). Only the optimum concentration was used in subsequent cultures. 
Table IV Details of stimulating agents added to lymphocyte cultures

\begin{tabular}{|c|c|}
\hline Antigen & $\begin{array}{l}\text { Amount added per } 5 \mathrm{ml} \text {. } \\
\text { culture }\end{array}$ \\
\hline $\begin{array}{l}\text { (A) Recent immunization } \\
\text { (i) Tetanus toxoid }{ }^{1} \\
\text { (ii) Influenza virus } \\
\text { vaccine } 2 \\
\text { 'Flugen' (Batch nos. } \\
29 / 1,36 / 5 \\
\text { (iii) Undulant fever } \\
\text { vaccine }^{3}\end{array}$ & $\begin{array}{l}0.1 \mathrm{ml} .(1 / 1000 \mathrm{dil} .) \\
0 \cdot 1 \mathrm{ml} .(1 / 1000 \mathrm{dil} .)\end{array}$ \\
\hline $\begin{array}{l}\text { (B) Other antigens } \\
\text { Tuberculoprotein (PPD) } \\
\text { Streptokinase }^{5} \\
\text { Endotoxin (S. lipopoly- } \\
\text { saccharide) } \\
\text { Mumps skin antigen } \\
\text { Diphtheria toxoid } \\
\text { B. } \text { pertussis }^{8}\end{array}$ & $\begin{array}{l}5 \mu \mathrm{g} . \\
10 \text { units } \\
0 \cdot 01 \mu \mathrm{g} . \\
0 \cdot 1 \mathrm{ml} .(1 / 100 \mathrm{dil} .) \\
0 \cdot 1 \mathrm{ml} .(1 / 1000 \mathrm{dil} .) \\
0 \cdot 1 \mathrm{ml} .(1 / 100 \text { dil. })\end{array}$ \\
\hline
\end{tabular}

1 Glaxo 2 Beecham Research Labs. 3 Parke Davies \& Co. 4 Evans Medical Ltd. 5 Lederle 6 Difco 7 Lilly \& Co. 8 Burroughs Wellcome.

\section{Skin reactions}

Skin tests were performed with $0 \cdot 1 \mathrm{ml}$. of a $1: 1,000$ solution of PPD and with $0.1 \mathrm{ml}$. of a streptokinasestreptodornase solution containing 10 units of streptokinase. The areas of erythema and induration were recorded at 24 and 48 hours after injection, using circles of standard diameter (Bencard). The results given are the maximum extent of erythema.

\section{Circulating antibody}

(a) Influenza vaccine Each dose of 'Flugen' influenza vaccine contained a total of 15,000 haemagglutinating units of approximately equal amounts of the $A$ and $B$ strains of influenza virus prevalent during the years 1959-66. Children under the age of 12 years were given half the adult dose. Antibody titres were estimated by the haemagglutination-inhibition method using the A2/England/1961 and the B/England/1969 influenza strains as antigens. Details of this method have been previously described (Heath, Tyrrell, and Peto, 1962).

(b) Tetanus toxoid $0.5 \mathrm{ml}$. tetanus toxoid (Glaxo) was given. Antitoxin responses were measured by in vivo titration, using the mouse subcutaneous method.

(c) Brucella vaccine Each dose of brucella vaccine contained $200 \times 10^{6}$ organisms in $0.1 \mathrm{ml}$. (Parke Davis, Detroit). Antibody titres were determined using an agglutination technique (Bailey and Scott, 1962) with Brucella abortus 0 suspension (Burroughs Wellcome) as antigen.

\section{Serum immunoglobulin levels}

Serum levels of IgA, IgG, and IgM were determined by a radial immunodiffusion method (Fahey and McKelvey, 1965), using sheep antisera kindly provided by the Department of Experimental Pathology, Birmingham University. Results were expressed as a percentage of the Medical Research Council normal human serum standard. This part of the investigation was confined to patients receiving cytotoxic drugs (Group A).

Results

LYMPHOCYTE TRANSFORMATION

(a) Response to PHA (Fig. 1)

Lymphocytes from patients with rheumatoid arthritis in Group A, obtained before treatment with cytotoxic

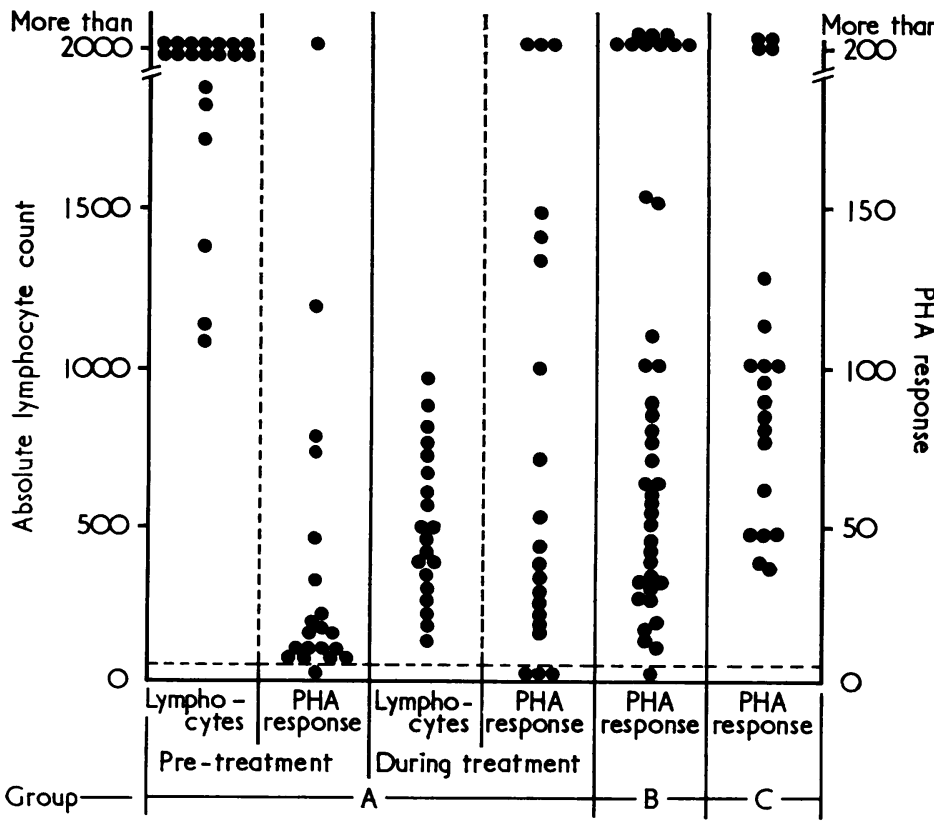

FIG. 1 Relation between absolute lymphocyte count and response of peripheral Th lymphocytes to PHA stimulation.

$\mathrm{PHA}$ response $=$

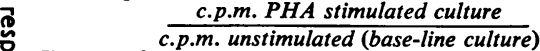
Horizontal - - - = lower limit c.p.m. baseline cultures: Gp. A Before cytotoxic drugs $103.1+52.4$ During cytotoxic drugs $\quad 95.6 \pm 51.4$ After cytotoxic drugs $\quad \mathbf{8 1 . 0} \pm \mathbf{4 7 . 8}$ Gp. B Not receiving cytotoxic drugs $91.8+44 \cdot 5$ Gp. C Controls $77.8 \pm 34.6$ 
drugs, responded poorly to PHA compared with those from patients in Group B. This was a consistent finding in repeated cultures and emphasizes that the patients in this group were highly selected. Nevertheless, the blood lymphocyte counts were initially within the normal range (Fig. 1). During the course of treatment with cytotoxic drugs, the ability of the lymphocytes from these patients to respond to PHA improved and the lymphocytes from three patients which were initially totally unresponsive to PHA recovered the ability to respond to this stimulus. The PHA response of patients from Group A after treatment was comparable to that observed in patients with rheumatoid arthritis (Group B) and in normal controls (Group C), although the blood lymphocyte count had fallen to low levels at this time (Fig. 1). The increased response to PHA in patients in Group A observed after treatment is highly significant $(\mathrm{t}=2 \cdot 56 ; \mathrm{P}=<0 \cdot 01)$.

\section{(b) Response to naturally encountered antigens}

$P P D$ Although ten patients from Group A had given a positive skin test to PPD in the year preceding treatment with cytotoxic drugs, the lymphocytes of only four of these patients were transformed by PPD in vitro (Fig. 2). However, positive lymphocyte transformation to PPD was obtained in all but one of these patients after treatment with cytotoxic drugs had been started. Lymphocytes from patients with negative skin tests did not respond to PPD in vitro at any stage. PPD induced transformation in seventeen of the twenty patients in Group B and in all seven of the controls in Group $\mathrm{C}$ who gave a positive skin test.

Streptokinase and endotoxin The number of patients in Group $A$ in whom transformation could be induced by streptokinase increased from four before treatment to twelve during treatment, a proportion comparable to that obtained in subjects in Groups $B$ and C. A consistent response was obtained in serial cultures from individual patients (Fig. 2). A similar increase was also observed in the number of patients whose lymphocytes responded to endotoxin after treatment with cytotoxic drugs was initiated ( 1 out of 16 increasing to 8 out of 17).

Stimulation by other antigens (Group A) The lymphocytes of three patients were transformed in vitro by poliomyelitis vaccine, of two by diphtheria toxoid, and of a further two by mumps antigen. These responses were not affected by treatment with cytotoxic drugs.

\section{(c) Response of lymphocytes to immunizing antigens}

The lymphocytes from only three of nine patients in Group A immunized with 'Flugen' before treatment with cytotoxic drugs were transformed by the immunizing antigen in vitro. In contrast, lympho-

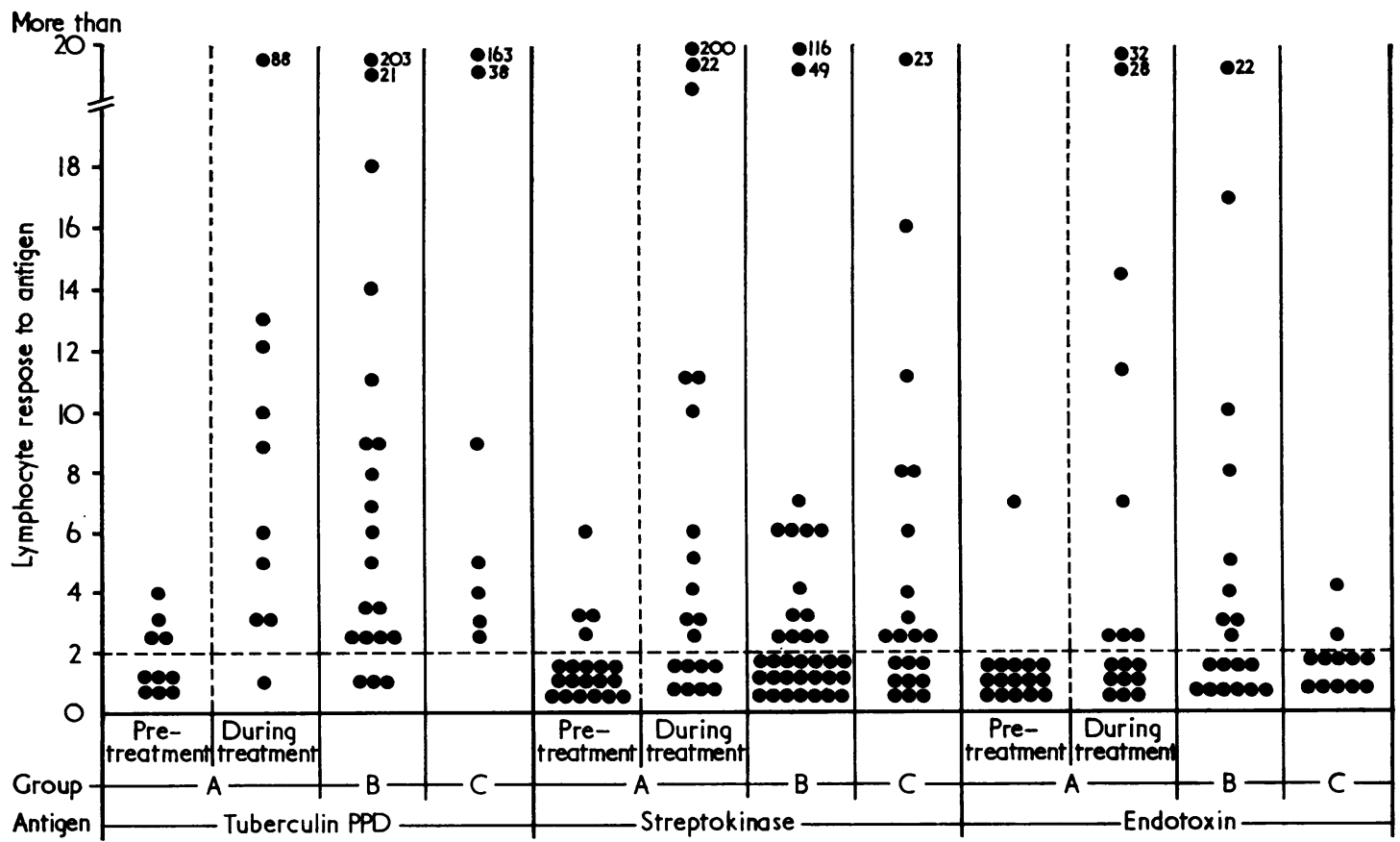

FIG. 2 Lymphocyte transformation in vitro induced by tuberculoprotein (PPD), streptokinase, and endotoxin.

Response to antigen $=\frac{c . p \cdot m \text {. stimulated culture }}{c . p . m \text {. base-line culture }}$

Horizontal - - - - = lower limit of significant response 


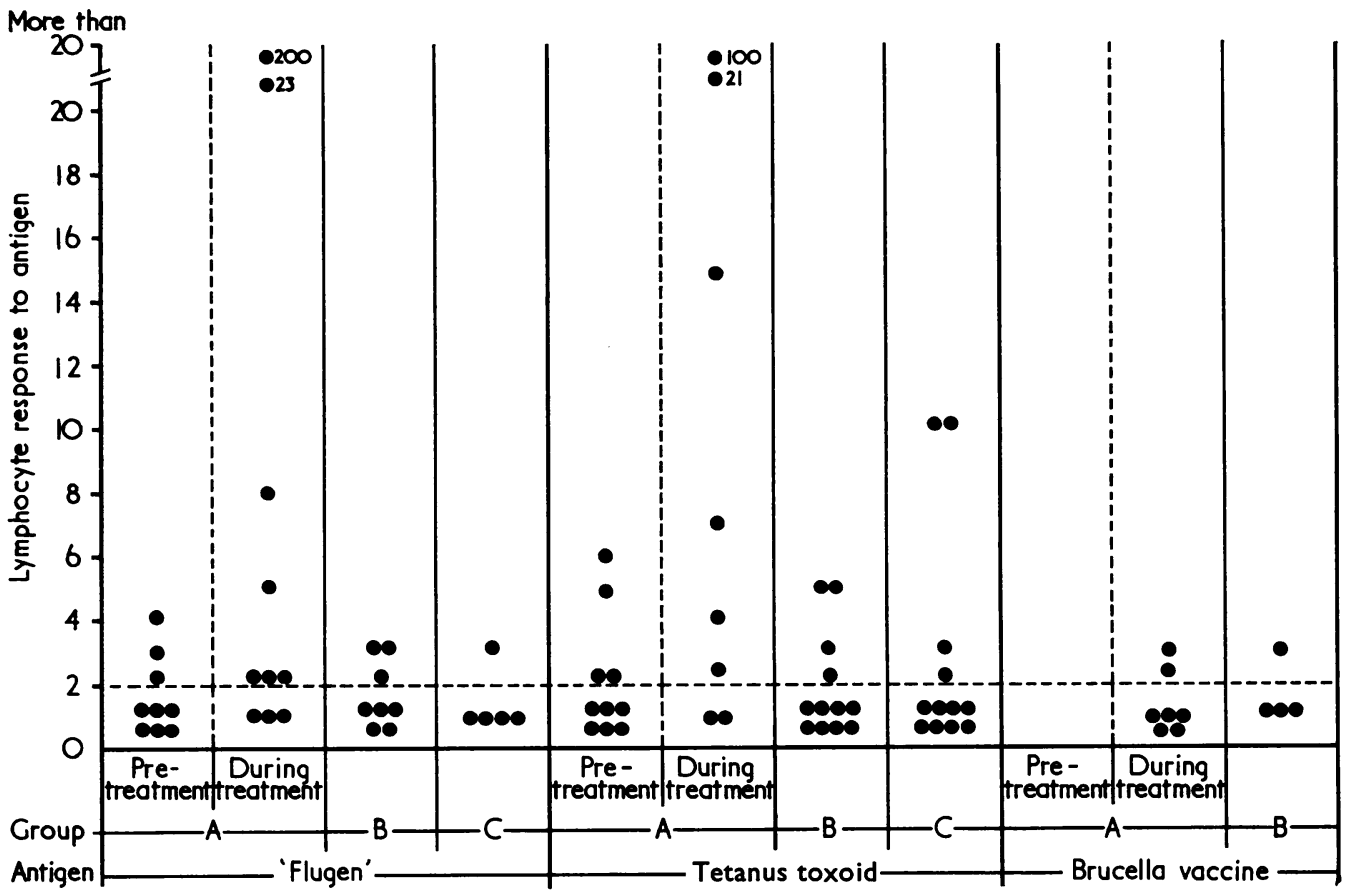

FIG. 3 Lymphocyte transformation in response to antigens after immunization.

Horizontal - - - = lower limit of significant response

cytes from seven of ten patients immunized during the course of treatment produced a positive response (Fig. 3, above). Similarly, the lymphocytes from six to eight patients immunized with tetanus toxoid whilst receiving cytotoxic drugs responded in vitro to this antigen, while only four of ten patients immunized before treatment showed a positive response. These findings show clearly that cytotoxic drugs failed to suppress lymphocyte transformation in vitro provoked by antigens administered during treatment. There is even a suggestion that this form of response was enhanced by administration of cytotoxic drugs, not only in comparison with the findings in Group A patients before treatment, but also in comparison with findings in subjects in Groups B and $C$. However, insufficient patients were tested for this possibility to be statistically verified.

Only a limited number of Group A patients were immunized with brucella antigen during the course of treatment with cytotoxic drugs. This antigen induced lymphocyte transformation as readily in these patients as in members of Group B.

\section{CORRELATION BETWEEN RESULTS OBTAINED} WITH SCINTILLATION COUNTING AND

AUTORADIOGRAPHY

The results of lymphocyte stimulation tests presented above are those obtained by $\mathrm{H}^{3}$ thymidine incorporation measured by scintillation counting. In this study, as in a previous one (Denman and Denman, 1968), these results were in good agreement with the numbers of labelled cells in autoradiographs and the details of the autoradiographical findings are therefore omitted.

\section{ANTIBODY RESPONSE}

\section{(a) Influenza vaccine}

The majority of patients in Groups A and B produced antibody to virus of the $A$ and $B$ strain, even when antigen was given during the course of treatment with cytotoxic drugs (Table V; Fig. 4, overleaf). The four healthy controls, aged 21-50 years, immunized with influenza vaccine produced antibody in titres comparable to those found in the patients with rheumatoid arthritis.

\section{(b) Tetanus toxoid}

Approximately half the patients in Group A produced appreciable antibody titres to tetanus toxoid (Table V). The administration of cytotoxic drugs did not appear to influence the antibody response. Only three of the ten patients in Group B immunized with tetanus toxoid produced detectable amounts of antibody, although these patients had never received cytotoxic drugs. Four controls, aged $60-70$ years, failed to respond to tetanus toxoid, but the remainder produced antibody in the expected titres. 
Table V Immunological responses of 20 patients with rheumatoid arthritis and Still's disease treated with cytotoxic drugs (group $A$ )

\begin{tabular}{|c|c|c|c|c|c|c|c|c|c|c|c|c|c|c|c|c|c|c|c|c|}
\hline \multirow{3}{*}{$\begin{array}{l}\text { Patient } \\
\text { no. }\end{array}$} & & & & \multicolumn{4}{|c|}{ Before cytotoxic drugs } & \multirow{2}{*}{\multicolumn{4}{|c|}{$\frac{\text { During cytotoxic drugs }}{\text { Ag. Lymph. Antibody response }}$}} & \multicolumn{9}{|c|}{ Immunoglobulins } \\
\hline & \multicolumn{3}{|c|}{ PHA response } & \multirow[t]{2}{*}{$A g$} & \multicolumn{3}{|c|}{ Lymph. Antibody response } & & & & & \multicolumn{3}{|l|}{$\overline{\lg G}$} & \multicolumn{3}{|l|}{$\operatorname{Ig} M$} & \multicolumn{3}{|l|}{$\operatorname{Ig} A$} \\
\hline & $B$ & $D$ & $A$ & & & B Ag. & $A$ Ag. & & & $B A g$ & $A$ Ag. & $B$ & $D$ & $A$ & $B$ & $D$ & $A$ & $B$ & $D$ & $A$ \\
\hline 1 & 0 & 0 & 0 & $T$ & 0 & $<0.01$ & $<0.01$ & $\mathrm{~F}$ & 0 & 8,16 & 32,16 & 125 & 85 & 120 & 275 & 195 & 330 & 205 & 155 & 175 \\
\hline 2 & 19 & 300 & 33 & $\mathrm{~T}^{*}$ & 0 & $<0.01$ & $<0.01$ & $\stackrel{F}{T}$ & $\begin{array}{l}23 \\
21\end{array}$ & $\begin{array}{l}32,<8 \\
<0 \cdot 01\end{array}$ & $\begin{array}{c}256,64 \\
10-20\end{array}$ & 100 & 85 & 65 & 240 & 35 & 60 & 130 & 95 & 75 \\
\hline 3 & 2 & 0 & 0 & $\begin{array}{l}\mathrm{T} \\
\mathrm{F}\end{array}$ & $\begin{array}{l}0 \\
2\end{array}$ & $\begin{array}{l}<0.01 \\
\quad 8,<8\end{array}$ & $\begin{array}{c}5 \cdot 0 \\
2048,16\end{array}$ & B & 2 & 0 & 160 & 30 & 20 & - & 250 & 75 & - & 60 & 35 & - \\
\hline 4 & 3 & 23 & - & $\mathbf{T}$ & 0 & $2-5$ & $5-10$ & $\begin{array}{l}\text { F } \\
\text { B }\end{array}$ & $\begin{array}{l}0 \\
0\end{array}$ & $\underset{0}{<8,<8}$ & $\begin{array}{l}64,32 \\
20\end{array}$ & 55 & 25 & - & 185 & 155 & - & 145 & 35 & - \\
\hline 5 & 50 & 100 & 80 & $\mathrm{~T}^{*}$ & 0 & $<0.01$ & $<$ & $\underset{T}{\mathbf{F}}$ & $\begin{array}{l}2 \\
4\end{array}$ & $\begin{array}{c}<8,<8 \\
0.01\end{array}$ & $<\underset{1-2}{<,<8}$ & 50 & 45 & 35 & 315 & 160 & 185 & 60 & 50 & 30 \\
\hline 6 & 9 & 16 & 13 & $T$ & 0 & $<0.01$ & $<0.01$ & 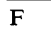 & 0 & $8,<8$ & 16,8 & 190 & 165 & - & 340 & 170 & - & 155 & 105 & - \\
\hline 7 & 65 & 7 & - & $\begin{array}{l}\mathrm{T} \\
\mathrm{F}\end{array}$ & $\begin{array}{l}0 \\
0\end{array}$ & $\begin{array}{r}0 \cdot 01 \\
16,16\end{array}$ & $\begin{array}{c}1-2 \\
2048,246\end{array}$ & B & 0 & 0 & 320 & 200 & 185 & - & 125 & 200 & - & 90 & 85 & - \\
\hline 8 & 0 & 55 & - & $\mathbf{F}$ & 0 & $8,<8$ & $1024,<8$ & B & 0 & 0 & 10 & & - & & & - & & & - & \\
\hline 9 & 34 & 140 & 400 & $\mathbf{T}$ & 2 & 0.01 & $0 \cdot 5-1 \cdot 0$ & $F$ & 2 & $<8,8$ & 16,256 & 50 & 30 & 45 & 270 & 185 & 240 & 120 & 70 & 75 \\
\hline 10 & 80 & 137 & 70 & $\mathbf{F}$ & 0 & $<8,<8$ & 256,32 & $\mathrm{~T}$ & 0 & 0.01 & 0.01 & 30 & 30 & 30 & 75 & 70 & 60 & 120 & 90 & 85 \\
\hline 11 & 4 & 40 & 28 & $\mathbf{F}$ & 4 & $64,<8$ & $128,<8$ & $\mathbf{T}$ & 2 & $<0.01$ & $<\cdot 0 \cdot 1$ & 150 & 85 & 115 & 435 & 245 & 185 & 155 & 70 & 155 \\
\hline 12 & 0 & 0 & - & $F$ & 0 & $16,<8$ & 32,8 & B & 0 & - & - & 30 & 55 & - & 105 & 150 & - & 60 & 120 & - \\
\hline 13 & 3 & 52 & - & $\mathrm{T}^{*}$ & 0 & $<0.01$ & $<0.01$ & $\mathrm{~F}$ & $\begin{array}{l}8 \\
7 \\
\end{array}$ & $\begin{array}{r}64,16 \\
<0.01 \\
\end{array}$ & $\begin{array}{l}1024,2048 \\
<0.01\end{array}$ & 260 & 30 & - & $\overline{240}$ & 140 & - & $\overline{175}$ & 70 & - \\
\hline 14 & 44 & 213 & - & $T$ & 6 & $<0.01$ & $0.05-1.0$ & & & - & & 25 & 20 & - & 425 & 350 & - & 130 & 85 & - \\
\hline 15 & 16 & 46 & 3 & $\mathbf{F}$ & 0 & $<8,<8$ & $8,<8$ & $\mathrm{~T}$ & 0 & $<0.01$ & $<0.01$ & 260 & 150 & 200 & 260 & 115 & 130 & 300 & 165 & 190 \\
\hline 16 & 34 & 9 & - & $\mathbf{T}$ & 0 & $<0.01$ & $<0.01$ & $\mathbf{F}$ & 5 & $<8,<8$ & $<8,<8$ & 70 & 60 & - & 330 & 270 & - & 180 & 135 & 二 \\
\hline 17 & 120 & 150 & 100 & $\mathrm{~T}^{*}$ & 0 & $<0.01$ & $<0.01$ & $\begin{array}{l}\mathrm{T} \\
\mathrm{T} \\
\end{array}$ & $\begin{array}{r}2 \\
100 \\
\end{array}$ & $\begin{array}{c}64,<8 \\
0.01\end{array}$ & $\begin{array}{r}128,8 \\
0.01 \\
\end{array}$ & 105 & 40 & - & 210 & 17 & - & 140 & 20 & - \\
\hline 18 & 265 & 316 & - & $\begin{array}{l}\mathrm{T} \\
\mathrm{F}\end{array}$ & $\begin{array}{l}5 \\
3\end{array}$ & $\begin{array}{l}0 \cdot 2-0 \cdot 5 \\
16,8\end{array}$ & $\begin{array}{c}20-50 \\
128,512\end{array}$ & B & 3 & 0 & 1280 & 20 & 35 & - & 35 & 140 & - & 100 & 180 & - \\
\hline 19 & 3 & 34 & - & $\mathbf{F}$ & 0 & $8,<8$ & 1024,128 & B & 0 & 0 & 1280 & & - & & & - & & & - & \\
\hline 20 & 29 & 400 & 48 & $T$ & 2 & $<0.01$ & $<0.01$ & $\mathrm{~F}$ & $\begin{array}{r}200 \\
15\end{array}$ & $\begin{array}{c}<8,<8 \\
0 \cdot 01\end{array}$ & $\underset{2-5}{<8},<8$ & 124 & 50 & 135 & 100 & 45 & 85 & 60 & 35 & 115 \\
\hline
\end{tabular}

Patient numbers correspond to those in Table I.

$\mathrm{T}=$ Tetanus toxoid. Antibody response in units $/ \mathrm{ml}$.

$\mathrm{F}=$ Influenza vaccine. Antibody response in haemagglutination inhibition units. Titre to influenza A before comma; Titre to influenza $\mathrm{B}$ after comma.

$\mathbf{B}=$ Brucella vaccine. Antibody response in $\log _{2}$ haemagglutination titres.

* Responses of patients who received only one injection of tetanus toxoid before cytotoxic drug treatment, results not included in Fig. 4.

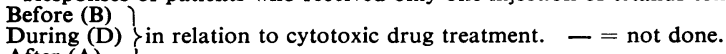

After (A) $J$

\section{(c) Brucella antigen}

Antibody to brucella antigen was produced by all seven of the patients in Group A immunized with this antigen during treatment with cytotoxic drugs. Similar antibody titres were obtained in the four patients from Group B immunized with this antigen (Fig. 4, opposite).

\section{SKIN TESTS}

Considerable variation was observed in the intensity of skin reaction to PPD and streptokinase in patients with rheumatoid arthritis tested serially before and during treatment with cytotoxic drugs. However, cytotoxic drugs had no obvious effect on this form of immune response. Nevertheless, the character of the reaction may have been affected in a way that would not have been revealed without histological examination.

\section{SERUM IMMUNOGLOBULINS}

The interpretation of the effects of cytotoxic drugs on serum immunoglobulin levels was complicated by the occurrence of amyloid disease in some patients. IgG levels were less than 60 per cent. of the normal standard in five of seven patients with this complication before treatment with cytotoxic drugs. The precipitious fall in IgG level that occurred in a sixth patient with amyloidosis during the course of treatment (Case 13, Table V) could have resulted from a 


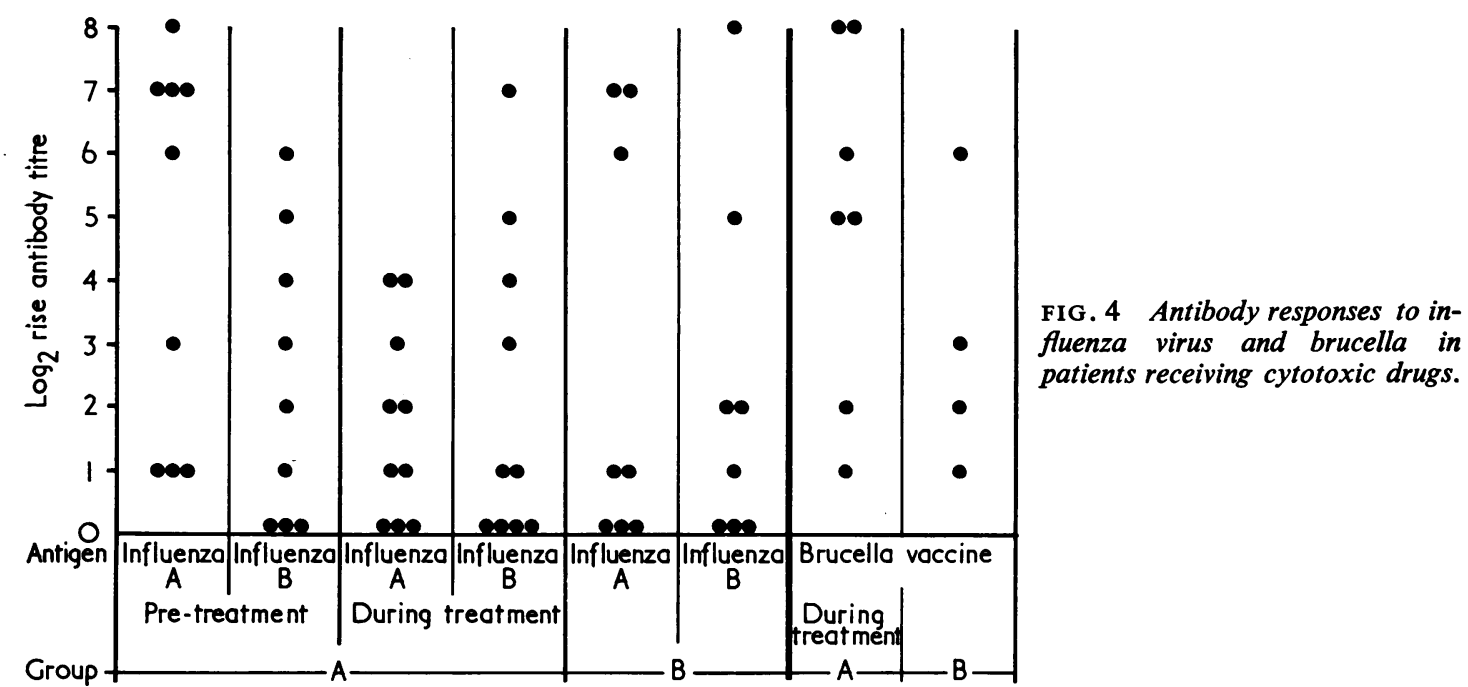

deterioration in his nephrotic syndrome rather than from a direct effect of the cytotoxic drug on IgG producing-lymphoid cells. Nevertheless IgG levels fell by 40 per cent or more during treatment with cytotoxic drugs in seven of the remaining thirteen patients in Group A. Thirteen patients showed a fall in IgA level of a similar magnitude during treatment, and ten patients showed a fall in IgM level (Table V). In five patients a rise in immunoglobulin level followed the cessation of treatment with cytotoxic drugs, suggesting a direct effect of these drugs on immunoglobulin synthesis. In three patients a fall in the titre of rheumatoid factor occurred during treatment with cytotoxic drugs.

CORRELATION BETWEEN IMMUNOLOGICAL AND CLINICAL FINDINGS IN PATIENTS WITH RHEUMATOID ARTHRITIS TREATED WITH CYTOTOXIC DRUGS

The clinical condition of most patients did not change sufficiently for any clear conclusions to be reached. Nevertheless falls in erythrocyte sedimentation rate, titres of rheumatoid factor, and immunoglobulin levels were observed during treatment with cytotoxic drugs at a time when there was no evidence of immunosuppression (Tables $I$ and V). These features are illustrated by the response to treatment of Case 2 (Fig. 5, overleaf).

\section{Discussion}

Several reports have claimed that cytotoxic drugs benefited patients with rheumatoid arthritis and other chronic inflammatory diseases (Galens, Bull, and Bartholomew, 1964; Lorenzen and Videbaek, 1965; Corley, Lessner, and Larsen, 1966; Renier, Deshayes, Besson, Barazer, Delahaye, and Bregeon, 1967; Kahn, Bedoiseau, and de Sèze, 1967; Fosdick, Parsons, and Hill, 1968), although these reports have been criticized on the grounds that acceptable controlled trials were not undertaken (Christian, 1967; O'Brien, 1968). Many of the therapeutic issues will undoubtedly be clarified by the studies of Mason and others (1969).

The rationale for the use of cytotoxic drugs in treatment of 'autoimmune' diseases rests on the assumption that they suppress the presumed immunological causes of these disorders. Although cytotoxic drugs are immunosuppressive in some animals (Borel and Schwartz, 1964), recent reviews (Gabrielsen and Good, 1967; Schwartz, 1967) have stressed that the degree of immunosuppression produced by these drugs is markedly influenced by the nature, quantity, and timing of the immunization procedure and by the species of the recipient. It is also clear that cytotoxic drugs owe their immunosuppressive effects in animals to their ability to interfere with the proliferation of lymphoid cells at some but not all stages of the immune response (Berenbaum, 1969), and that the secondary antibody response is relatively resistant to these drugs (Butler and Coons, 1964). In animal models of autoimmune disease, cytotoxic drugs have been given during the induction process with good effect (Hoyer, Good, and Condie, 1962). In man the drugs have been used to treat established 'autoimmune' disease at a stage when the immunological processes involved must be considered analogous to those of the secondary antibody response and of established cellular immunity. Animal experiments suggest that these immunological processes are resistant to the immunosuppressive action of cytotoxic drugs. This view is supported by the findings of Page, Condie, and Good (1964) and Moens and Brocteur (1965), who showed that established immune responses in patients with rheumatoid arthritis, systemic lupus erythematosus, and plasma cell hepatitis were 


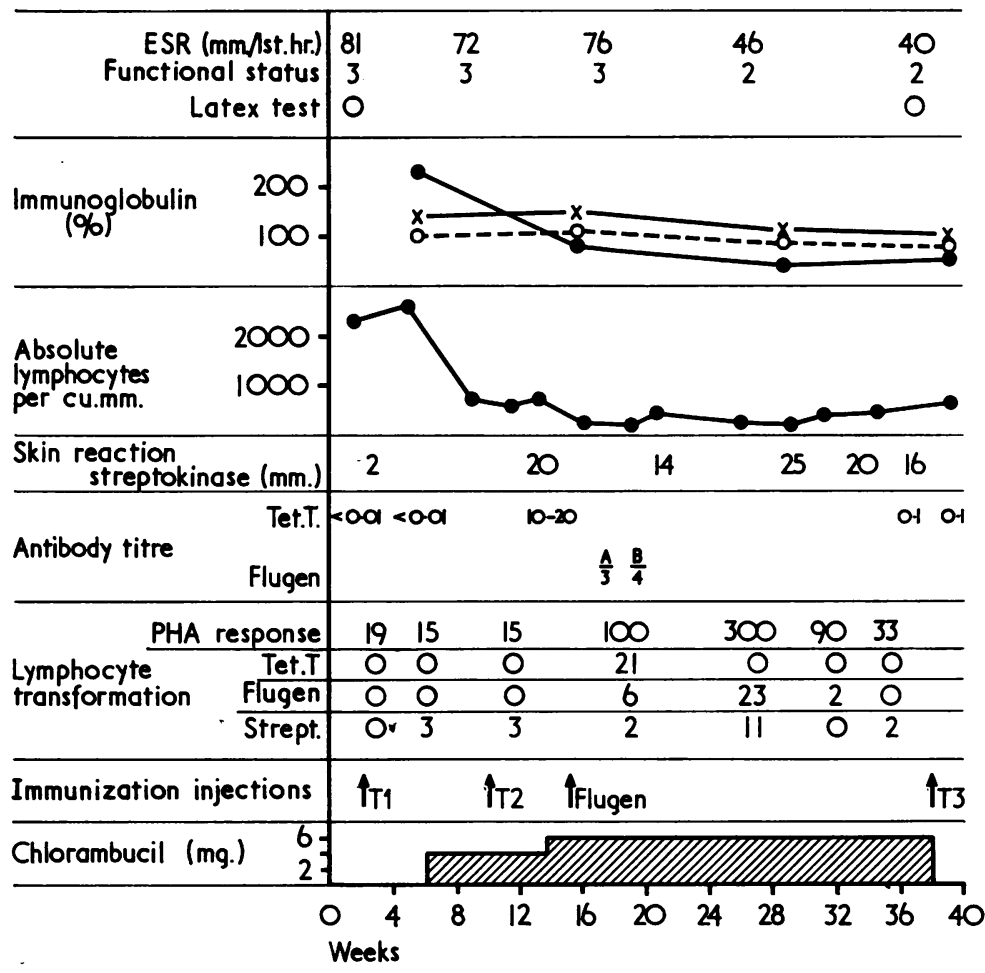

FIG. 5 Relation 'between clinical course and immunological responses in Patient 2 (Table I). $\equiv I g M \quad O \equiv \operatorname{Ig} G \quad \times \equiv \operatorname{Ig} A$

indeed resistant to treatment with purine analogues. However, Swanson and Schwartz (1967) showed that the primary antibody response to keyhole-limpet haemocyanin of twenty patients with autoimmune diseases was affected by treatment with azathioprine and amethopterin. Thirteen of these patients produced IgM antibody exclusively and the remainder did not respond at all to the antigen. The secondary antibody response of the majority of the patients was also affected, although their isoagglutinin titres were little impaired. It seems probable that treatment with cytotoxic drugs was partially responsible for the partial immunosuppression observed in these patients, but the underlying disease process may also have played some part.

The immunological responses tested in our study must all be regarded as secondary, since even in the absence of a history of previous immunization, naturally acquired immunity cannot be excluded. Some suppression of the production of circulating antibody was seen in both groups of patients with rheumatoid arthritis, but this was no more marked in patients receiving azathioprine or chlorambucil at the time of immunization than in patients with similar disease activity who were not receiving these drugs. Although the antibody response of patients with rheumatoid arthritis is not usually abnormal (Rhodes, Scott, Markham, and Monk-Jones, 1969), the patients in the present study were suffering from severe complicated disease, so that some depression of this response was not surprising.

Lymphocyte transformation was studied in considerable detail as ablation of the responses mediated by circulating lymphocytes would appear to be the best means of assaying the immunosuppressive action of cytotoxic drugs. Thus, suppression of the PHA response by azathioprine has been used by Tennenbaum, St. Pierre, and Cerilli (1968) as a guide to therapy in renal transplantation. However, the transformation of lymphocytes by PHA was not suppressed in our patients with rheumatoid arthritis receiving cytotoxic drugs and may even have been enhanced. This form of lymphocyte reactivity is generally accepted as indicating immunological memory for stimulating antigen, although evidence has also been presented that antigen-antibody complexes may initiate transformation (Möller, 1969). There is good evidence that lymphocytes which respond by blast transformation can be classed as long-lived antigen-sensitive cells (Miller and Mitchell, 1969; Davies, 1969), different in origin and life-span from the antibody-forming lymphocytes which can be detected in the peripheral blood after immunization (Simons and Fitzgerald, 1969). It seems likely, therefore, that antigen-sensitive lymphocytes in the blood and some antibody-forming cells escape inactivation by cytotoxic drugs despite the profound fall in the circulating lymphocyte count.

The enhancement of cellular transformation seen. 
in our study may have been analogous to the enhancement of antibody production seen after administration of 6-mercaptopurine (Chanmougan and Schwartz, 1966) and low dose irradiation (Dixon and McConahey, 1963). This phenomenon was also encountered in three of the patients of Swanson and Schwartz (1967).

The recovery of lymphocyte responsiveness in vitro as a result of treatment with cytotoxic drugs may have followed a decline in 'autoantibody' production, reflected by the observed fall in levels of rheumatoid factor and IgM in some patients, thereby removing a source of competition for antigensensitive cells. Competition of this nature has been advanced as the explanation of the depression of the immune response observed in NZB $\times N Z W \quad F_{1}$ hybrid mice with renal disease (Salomon and Benveniste, 1969).

Skin reactions were not suppressed by cytotoxic drugs, although increased reactions did not accompany the increase in lymphocyte transformation. A dissociation between these two forms of the immune response has also been noted by Leventhal, Waldorf, and Talal (1967).

There can be no doubt that the cytotoxic drugs used in this study had profound biological effects, including lymphopenia, reduction in serum levels of immunoglobulins and rheumatoid factor, and, unfortunately, suppression of the red cell series and platelet precursors in five patients. Nevertheless, it is perhaps not surprising that chlorambucil and azathioprine failed to suppress lymphocyte transformation and the secondary antibody response, since it is known that long-lived lymphocytes and plasma cells in rat lymph nodes are resistant to the action of the antimetabolic drugs cyclophosphamide and 6-mercaptopurine (Miller and Cole, 1967). It has also been shown previously that the toxicity of cytotoxic drugs is independent of their immunosuppressive effects (Berenbaum and Brown, 1964).

Hurd and Ziff (1968) have shown that 6-mercaptopurine suppresses blood 'mononuclear cells' which are probably bone-marrow-derived macrophage precursor cells and not circulating small lymphocytes. The importance of bone-marrow-derived macrophages in chronic inflammatory lesions has been clearly demonstrated (Spector and Willoughby, 1968; Lubaroff and Waksman, 1968). The possibility that these are also the cells primarily affected in man by cytotoxic drugs is strengthened by our observation that the 'mononuclear cells' appearing in skin windows in patients receiving these drugs are reduced in number and atypical in morphology (Denman and Denman, unpublished observations). Thus a fall in blood lymphocyte count after treatment with cytotoxic drugs provides no indication that cells concerned with the initiation and maintenance of immune responses have necessarily been ablated. Indeed a relative enrichment of the surviving lymphocyte population of antigen-sensitive cells may have accounted for the enhanced response to PHA and other antigens. Even the susceptibility to infection of patients on these drugs may be the consequence of macrophage rather than of lymphocyte depletion (Mackaness, 1969). The converse situation is seen in mice receiving antilymphocyte globulin (Denman, Denman, and Embling, 1968), in which a normal blood lymphocyte count masks the depletion of long-lived small lymphocytes needed for antigen recognition.

It could be argued that the patients in the present study were suffering from disease which was too advanced for successful treatment. This is particularly true for the patients with amyloidosis, whose poor prognosis is well recognized (Smith, Ansell, and Bywaters, 1968). Thus the clinical observations in this study give no useful answer to the question lucidly posed by Swanson and Schwartz (1967) whether immunosuppression is a necessary, irrelevant, or undesirable accompaniment of treatment with cytotoxic drugs. The same questions could well be asked about the apparent ability of these drugs to restore the responsiveness of lymphocytes from our patients to in vitro stimulation. Further studies, continued for longer periods, will be needed to establish these points and it will be necessary to take into account the blood concentrations of the immunosuppressive drugs (Bach, Dardenne, and Fournier, 1969).

\section{Summary}

The immunological responses of twenty patients with rheumatoid arthritis or Still's disease were studied before and during treatment with azathioprine or chlorambucil and were compared with those of 39 patients with the same diseases who were not receiving cytotoxic drugs and with twenty healthy controls. Patients were immunized with tetanus toxoid, influenza vaccine, and brucella antigen. Cytotoxic drugs failed to suppress skin reactivity and the production of circulating antibody. Lymphocyte transformation in vitro after stimulation with phytohaemagglutinin or antigens was also not suppressed and may even have been enhanced. Nevertheless, rheumatoid factor titres and serum immunoglobulin levels were reduced in many patients. It is concluded that cytotoxic drugs are not demonstrably immunosuppressive in patients with rheumatoid arthritis, and that antigen-sensitive and antibody-producing lymphocytes escape inactivation despite the concomitant peripheral lymphopenia.

The authors would like to thank Prof. E. G. L. Bywaters for his interest and Mr. P. Fiske for his help with the preparation of autoradiographs. 


\section{References}

Ansell, B. M., AND Bywaters, E. G. L. (1959) Bull. rheum. Dis., 9, 189 (Prognosis in Still's disease).

BACH, J. F., DARDENNE, M., AND FouRnIER, C. (1969) Nature (Lond.), 222, 998 (In vitro evaluation of immunosuppressive drugs).

BaIley, W. R., AND ScotT, E. G. (1962) “Diagnostic Microbiology", p. 277. Mosby, St Louis.

Berenbaum, M. C. (1969) Antibiot. et Chemother. (Basel), 15, 155 (The immune response and its suppression). AND BROWN, I. N. (1964) Immunology, 7, 65 (Dose-response relationships for agents inhibiting the immune response).

Borel, Y., AND Schwartz, R. (1964) J. Immunol., 92, 754 (Inhibition of immediate and delayed hypersensitivity in the rabbit by 6-mercaptopurine).

Butler, W. T., AND CoOns, A. H. (1964) J. exp. Med., 120, 1051 (Studies on antibody production. XII. Inhibition of priming by drugs).

Bywaters, E. G. L., AND ScotT, F. E. T., (1960) In "Recent Advances in Clinical Pathology, Series III", ed. S. C. Dyke, pp. 278-302. Churchill, London.

Chanmougan, D., AND Schwartz, R. S. (1966) J. exp. Med., 124, 363 (Enhancement of antibody synthesis by 6-mercaptopurine).

Christian, C. (1968) In "Immunopathology: Vth International Symposium. Mechanisms of Inflammation induced by Immune Reactions, Punta Ala, Italy, 1967', ed. P. A. Miescher and P. Grabar, p. 391. Schwabe, Basel/Stuttgart.

Corley, C. C., Lessner, H. E., and Larsen, W. E. (1966) Amer. J. Med., 41, 404 (Azathioprine therapy of 'autoimmune' diseases).

Davies, A. J. S. (1969) Transplant. Rev., 1, 43 (The thymus and the cellular basis of immunity).

Denman, A. M., Denman, E. J., And Embling, P. H. (1968) Lancet, 1, 321 (Changes in the life-span of circulating small lymphocytes in mice after treatment with anti-lymphocyte globulin).

Denman, E. J., AND Denman, A. M. (1968) Ann. rheum. Dis., 27, 582 (The lymphocyte transformation test and gold hypersensitivity).

Dixon, F. J., AND McConahey, P. J. (1963) J. exp. Med., 117, 833 (Enhancement of antibody formation by whole body X-radiation).

Empire Rheumatism CouncIl (1960) Ann. rheum. Dis., 19, 95 (Gold therapy in rheumatoid arthritis).

FAHEY, J. L., AND MCKelveY, E. M. (1965) J. Immunol., 98, 84 (Quantitative determination of serum immunoglobulins in antibody-agar plates).

Fosdick, W. M., Parsons, J. L., AND Hill, D. F. (1968) Arthr. and Rheum., 11, 151 (Preliminary report: long-term cyclophosphamide therapy in rheumatoid arthritis).

Gabrielsen, A. E., AND Good, R. A. (1967) Advance. Immunol., 6, 91 (Chemical suppression of the immune response).

Galens, G. J., Bull, F. E., AND Bartholomew, L. E. (1964) Arthr. and Rheum., 7, 735 (The treatment of rheumatoid arthritis with 6-mercaptopurine and azathioprine).

Heath, R. B., Tyrrell, D. A. J., AND Peto, S. (1962) Brit. J. exp. Path., 43, 444 (Serological studies with Sendai virus).

Hoyer, L. W., Good, R. A., AND Condie, R. M. (1962) J. exp. Med., 116, 311 (Experimental allergic encephalomyelitis: the effect of 6-mercaptopurine).

HuRD, E. R., AND ZIFF, M. (1968) Ibid., 128, 785 (Studies on the anti-inflammatory action of 6-mercaptopurine).

Kahn, M. F., Bedoiseau, M., ANd Sk̇ze, S. De (1967) Proc. roy. soc. Med., 60, 130 (Immunosuppressive elrugs in the management of malignant and severe rheumatoid arthritis).

Leventhal, B. G., WALdORF, D. S., AND TAlal, N. (1967) J. clin. Invest., 46, 1338 (Impaired lymphocyte transformation and delayed hypersensitivity in Sjögren's syndrome).

LORENZEN, I., AND VIDEBAEK, A. (1965) Lancet, 2, 558 (Treatment of collagen disease with cytostatics).

LUbaroff, D. M., AND Waksman, B. H. (1968) J. exp. Med., 128, 1425 (Bone marrow as source of cells in reactions of cellular hypersensitivity. I. Passive transfer of tuberculin sensitivity in syngeneic systems).

MaCKANESs, G. B. (1969) Ibid., 129, 973 (The influence of immunologically committed lymphoid cells on macrophage activity in vivo).

Mason, M. Currey, H. L. F., Barnes, C. G., Dunne, J. F., Hazleman, B. L., And Strickland, I. D. (1969) Brit. med. J., 1, 420 (Azathioprine in rheumatoid arthritis).

Miller, J. J., III, AND Cole, L. J. (1967) J. exp. Med., 126, 109 (Resistance of long-lived lymphocytes and plasma cells in rat lymph nodes to treatment with prednisone, cyclophosphamide, 6-mercaptopurine and actinomycin D).

Miller, J. F. A. P., AND Mrtchell, G. F. (1969) Transplant. Rev., 1, 3 (Thymus and antigen-reactive cells).

MöENS, C., AND Brocteur, J. (1965) Acta rheum. scand., 11, 212 (Treatment of rheumatoid arthritis with immunosuppressive drugs. I. Clinical study).

Möller, G. (1969) Clin. exp. Immunol., 4, 65 (Induction of DNA synthesis in normal human lymphocyte cultures by antigen-antibody complexes).

O'BRIEN, W. (1968) Arthr. and Rheum., 11, 698 (Cyclophosphamide vs. conservative treatment of rheumatoid arthritis).

Page, A. R., Condie, R. M., AND Good, R. A. (1964) Amer. J. Med., 36, 200 (Suppression of plasma cell hepatitis with 6-mercaptopurine). 
Renier, J.-C., Deshayes, P., Besson, J., Barazar, Ch., Delahaye, D., and Bregeon, Ch. (1967) Presse méd., 75, 2527 (Traitement de la polyarthrite rheumatoïde par le chlorambucil).

Rhodes, K., Scott, A., Markham, R. L., ANd Monk-Jones, M. E. (1969) Ann. rheum. Dis., 28, 104 (Immunological sex differences).

Salomon, J.-C., AND Benveniste, J. (1969) Clin. exp. Immunol., 4, 213 (The immune response in NZB $\times$ NZW F $F_{1}$ hybrid mice).

SchwarTZ, R. S. (1968) In "Immunopathology. Vth International Symposium, Punta Ala, Italy, 1967", ed. P. A. Miescher and P. Grabar, p. 360. Schwabe, Basel/Stuttgart.

Simons, M. J., AND Fitzgerald, M. G. (1969) Clin. exp. Immunol., 4, 55 (Apparent dissociation of antigen responsiveness and antibody production by human small lymphocytes in culture).

Singer, J. M., AND Plotz, C. M. (1956) Amer. J. Med., 21, 888 (The latex fixation test. I. Application to the serologic diagnosis of rheumatoid arthritis).

Smith, M. E., AnSell, B. M., AND Bywaters, E. G. L. (1968) Ann. rheum. Dis., 27, 137 (Mortality and prognosis related to the amyloidosis of Still's disease).

Spector, W. G., AND Willoughiy, D. A. (1968) J. Path. Bact., 96, 389 (The origin of mononuclear cells in chronic inflammation and tuberculin reactions in the rat).

Swanson, M. A., AND Schwartz, R. S. (1967) New Engl. J. Med., 227, 163 (Immunosuppressive therapy. The relation between clinical response and immunologic competence).

Tennenbaum, J. I., ST. Pierre, R. L., AND Cerilli, G. J. (1968) Transplantation, 6, 986 (Evaluation of immunosuppressive therapy and clinical course in renal transplants by in vitro lymphocyte transformation).

Valkrnsurg, H. A. (1963) In "Epidemiology of Chronic Rheumatism", ed. J. H. Kellgren, M. R. Jeffrey, and J. Ball, vol. 1, p. 337. Blackwell, Oxford.

VISCHER, T. L. (1966) Lancet, 2, 467 (Lymphocyte cultures in drug hypersensitivity).

Zutshi, D. W., ANSELl, B. M., AND Bywaters, E. G. L. (1969) Unpublished.

\section{RÉSUMÉ}

L'insuccès des médicaments cytotoxiques pour la suppression des réactions immunitaires chez les malades atteints de polyarthrite rhumatoide

Les réactions immunologiques de vingt malades atteints d'arthrite rhumatoïde ou de la maladie de Still ont été étudiées avant et pendant le traitement avec l'azathioprine ou la chlorambucile et ont été comparées à celles de 39 malades atteints des mêmes maladies et qui ne recevaient pas des médicaments cytoxiques et à vingt témoins sains. Les malades avaient été immunisés avec la toxoide du tétanos, le vaccin contre l'influenza et l'antigène du brucella. Les médicaments cytotoxiques n'avaient pas réussi à supprimer la réactivité de la peau et la production de l'anticorps en circulation. La transformation lymphocytique in vitro après stimulation par la phytohémagglutinine ou les antigènes n'a pas aussi été supprimée et a été même, peut-être, augmentée. Néanmoins, les titres du facteur rhumatoïde et les taux des immunoglobulines ónt été réduits chez beaucoup de malades. Il a été conclu que les médicaments cytotoxiques n'ont pas été démontrés comme étant immuno-répressifs chez les malades atteints d'arthrite rhumatoilde, et que les lymphocytes sensibles à l'antigène et produisants des anticorps échappaient à l'inactivation malgré la lymphopénie périphérique concomitante.

\section{SUMARIO}

Fracaso de las drogas citotóxicas en la supresión de las reacciones inmunes en pacientes con poliartritis reumatoide

Las reacciones inmunológicas de veinte pacientes con artritis reumatoide o enfermedad de Still fueron estudiadas antes del tratamiento y durante el tratamiento con azatioprina o clorambucil y fueron comparadas con las reacciones de 39 pacientes con las mismas enfermedades, pero que no estaban recibiendo drogas citotóxicas, y con veinte testigos sanos. Los pacientes fueron inmunizados con tétano toxoide, vacuna de influenza y antígeno de brucella. Las drogas citotóxicas no lograron suprimir la reactividad de la piel ni la producción de anticuerpos circulantes. La transformación in vitro de linfocitos después de estimulación con PHA o antígenos no fue tampoco suprimida y hasta pudiera haber sido incrementada. No obstante, los títulos del factor reumatoide y los niveles de suero inmunoglobulínico fueron reducidos en muchos pacientes. Se llega a la conclusión de que las drogas citotóxicas no son evidentemente inmunosupresivas en pacientes con artritis reumatoide, y que los linfocitos sensibles al antígeno y productores de anticuerpos eluden la inactivación, a pesar de la linfopenia periférica concomitante. 